\title{
Influence Product Quality and Quality of Service to Customer Satisfaction ( Renter ) Photocopy Machine Brand Konica Minolta in Surabaya
}

\author{
Kurniawan Agung Laksono ${ }^{1}$, Elok Damayanti², I Gede Arimbawa ${ }^{3}$ \\ kurniawan.al18@gmail.com¹, elok.damayanti@narotama.ac.id ${ }^{2}$,gede.arimbawa@narotama.ac.id4 \\ Narotama University, Faculty of economics and business, \\ J1. Arief Rahman Hakim Street number 51, Sukolilo, Surabaya
}

\begin{abstract}
This type of research is quantitative research, a population of 324 people from the customer (renter) photocopy machine Konica Minolta and taken 76 people using the formula slovin sample. The research method multiple regression analysis using SPSS 21. From the test results concluded that the hypothesis 1 hypothesis can be accepted, because of the results of the t test independent variable consisted of Product Quality and Service Quality partially significant effect on the variable Customer Satisfaction. Hypothesis 2 in accordance with the basis for a decision in the $\mathrm{f}$ test it can be concluded also that the variable quality of product and service quality variables simultaneously influence customer satisfaction.
\end{abstract}

keyword : Product Quality, Service Quality, Customer Satisfaction.

\section{INTRODUCTION}

The sophistication of the technology in the current era is very helpful in the world of work, especially in companies or banks, every day in working on a document required to be printed or copied into a lot to support the work in a company. With the photocopy machine would be very helpful in a way that is very easy to use, not only in the printing or copying but sophisticated photocopy can now also to scan, fax and print faster than regular printers with much larger number. One brand that photocopy is Konica Minolta.

Research on brand Konica Minolta photocopy was taken because of the importance of photocopiers in the office, the worker is the use of photocopies in supporting the work every day to print, and copy documents.

\section{Product quality}

\section{LITERATURE REVIEWS AND HYPOTHESIS}

In general, the definition of the product is anything that can be offered to the market to meet consumer needs. According to (Kotler and Armstrong 2006: 273) is the overall quality of the product quality or excellence of a product or service related to what is expected by the customer.

The product quality is an important aspect to be noticed by customers before they decide to use a product. The quality of products is a dynamic condition associated with the products, services, people, processes and environments that meet or exceed expectations (Tjiptono 2006: 51).

Dimensional quality of the product according to Tjiptono (2008: 34) is as follows:

1) The results Products (Performance).

2) The characteristics or additional feature (Features).

3) Reliability (Reliability).

4) Compliance with specifications (Conformance to Specification).

5) Durability (Durability)

6) Usability (Serviceability).

7) Aesthetics (Aesthetics).

8) Perceived Quality (Perceived Quality). 


\section{Service quality}

Quality of care that delivers excellent services by service providers to meet customer needs and desires as well as the accuracy of delivery to keep pace with customer expectations.

According to (Tjiptono 2000: 59) quality of service is the expected level of excellence and control over the level of excellence to meet customer desires.

According to Zeithaml and Berry (1985) in Tjiptono (2001: 70), concluded that there are five dimensions of ServQual (Service Quality), which is used to measure the quality of services, namely:

1. Tangibles (Physical Evidence)

Tangibles are clear evidence of the care and attention given by the service provider to the consumer.

2. Reliability (Reliability)

Reliability is the ability to provide accurate services in accordance with the promise and the company's ability to perform services in accordance with what has been promised in a timely manner.

3. Responsiveness (Response)

Responsiveness is the willingness to help customers and provide the appropriate services and the ability of the company which carried out directly by employees to perform fast and responsive service.

4. Assurance (Assurance)

Assurance or guarantee the knowledge and behavior of employees to build trust and confidence of customers in consuming services offered.

5. Emphaty (Concern)

Empathy is the ability of the company that carried out directly by the employee to provide individual attention to the consumer, as well as sensitivity to the needs of consumers.

\section{Customer satisfaction}

In creating a product the company would try to create a quality product and be able to set an attractive price adjusted raw material of the products to be able to give satisfaction to the customers in using its products. According to (Kotler and Keller, 2009: 138) that satisfaction is feeling happy or disappointed someone who emerged after comparing the performance or the result of a product in the mind of the performance or results you expected.

Satisfied customer behavior would be different from the behavior of dissatisfied customers. (Kotler 2007: 48) states the characteristics of consumers are satisfied as follows:

1. Loyal to the product

2. Any communication by word of mouth that is positive

3. The company is a major consideration.

\section{hypothesis}

Based on the literature review and the framework of the above ideas, the hypothesis used in this study are as follows:

H1: (X1, X2) positive and significant effect partially on (Y)

$\mathrm{H} 2$ : (X1, X2) positive and significant effect simultaneously on the (Y)

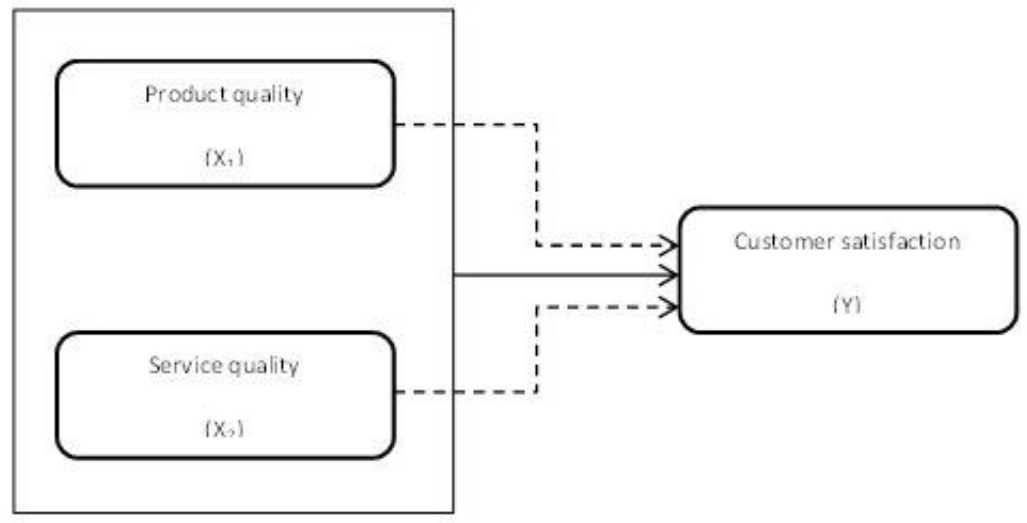




\section{METHODS}

\section{Populations \& Samples}

The population in this study is the customer who rented photocopy Konica Minolta brand in Surabaya, totaling 324 people.

In this study, samples taken as many as 76 people were obtained from the calculation using the formula Slovin.

\section{Data analysis technique}

1. Validity test used to measure the validity of the data is valid or invalid by using a questionnaire as a measuring tool. The questionnaire can be said to be valid if the statements in the questionnaire were able to express something that is measured by the questionnaire.

2. Analysis multiple linear regression is a technique to determine the correlation between a criterion variable with a combination of or more predictor variables.

The formula is as follows:

$$
Y=a+b 1 x 1+b 2 \times 2+e
$$

Information :

Y $=$ Customer Satisfaction

a $\quad=$ constant

$\mathrm{X} 1=$ Variable First (Quality Products)

$\mathrm{X} 2=$ Variable Second (Quality of Service)

b1 = Coefficient of regression variables $(\mathrm{X} 1)$

b2 = Coefficient of regression variables $(\mathrm{X} 2)$

$\mathrm{e} \quad=$ Standard Error

3. Hypothesis test is a procedure that is based on evidence samples used to determine whether the hypothesis is a reasonable statement and therefore not rejected or hypothesis was unnatural and therefore must be rejected.

1. Test $t$ (Partial) was used to test whether each independent variable regression coefficients have an influence or not the dependent variable.

2. Test $\mathrm{f}$ (Simultaneous) is a test in order to determine the relationship between three or more variables.

\section{RESULT AND DISCUSSION}

\section{Validity test}

The value of $r$ count all the indicators of the three variables above the 0.227 value of $r$ table. Thus, it is known that all values of $r$ count is greater than the value of $r$ table which means that all the questionnaire items declared valid and can be used as a data collection tool in the research that is done.

\section{Multiple Linear Regression Analysis}

\section{Coefficients $^{\mathrm{a}}$}

\begin{tabular}{|ll|l|l|l|l|l|}
\hline Model & \multicolumn{2}{|l|}{$\begin{array}{l}\text { Coefficients } \\
\text { unstandardized }\end{array}$} & $\begin{array}{l}\text { standardized } \\
\text { Coefficients }\end{array}$ & T & Sig. \\
\cline { 2 - 4 } & $\mathrm{B}$ & Std. Error & beta & & \\
\hline & $\begin{array}{l}\text { (Constant) } \\
\begin{array}{l}\text { Quality Products } \\
\text { (X1) }\end{array}\end{array}$ & .678 & .846 & & .801 & .425 \\
$\begin{array}{l}\text { Quality of Service } \\
\text { (X2) }\end{array}$ & .296 & .050 & .396 & 3,216 & .002 \\
& & .462 & 3,750 & .000 \\
\hline
\end{tabular}

a. Dependent Variable: Customer Satisfaction (Y)

Based on the above table, the regression equation obtained is:

$\mathrm{Y}=\mathrm{a}+\mathrm{b} 1 \times 1+\mathrm{b} 2 \times 2+\mathrm{e}$ 


$$
Y=0.678+0,162 \times 1+0,296 \times 2+e
$$

1. The value of the constant (a) is 0.678 indicates that if the independent variables consist of Product Quality (b1), Quality of Service (b2) = 0, then the Customer Satisfaction amounted to 0.678

2. Product Quality regression coefficient $(\mathrm{b} 1)=0.162$ showed a positive correlation direction (unidirectional) between the variable quality of products with variable customer satisfaction

3. The regression coefficient quality of service $(b 2)=0.296$ showed a positive correlation direction (unidirectional) between the variables of service quality and customer satisfaction variables

\section{Hypothesis testing}

T test (Partial)

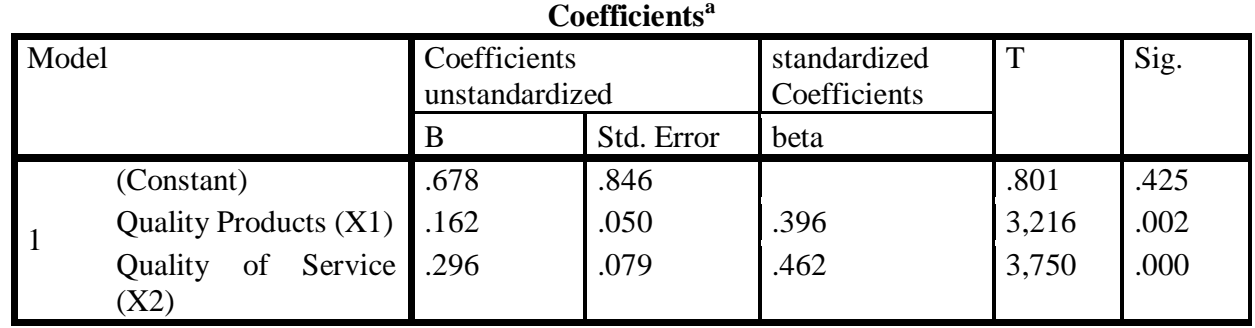

a. Dependent Variable: Customer Satisfaction (Y)

1. Variable Product Quality (X1) the Sig. $0.002<0.05$ and $3.216 \mathrm{t}$ count $>\mathrm{t}$ table 1.993

2. Variable Quality of Service (X2) the value of Sig. $0.000<0.05$ and $3.750 \mathrm{t}$ count $>\mathrm{t}$ table 1.993 The conclusion is the independent variable that consists of Product Quality and Service Quality partially significant effect on the variable Customer Satisfaction

\section{Test f (Simultaneous)}

\begin{tabular}{|ll|l|l|l|l|l|}
\hline Model & & Sum of Squares & df & mean Square & F & Sig. \\
\hline \multirow{3}{*}{1} & Regression & 77415 & 2 & 38708 & 77376 & $.000 \mathrm{~b}$ \\
& residual & 36519 & 73 & .500 & & \\
& Total & 113934 & 75 & & & \\
\hline
\end{tabular}

a. Dependent Variable: Customer Satisfaction (Y)

b. Predictors: (Constant), Quality of Service (X2), Quality Products (X1)

77.376 count unknown value $\mathrm{f}>\mathrm{f}$ table 3.12. So it can be concluded that the independent variables $(\mathrm{X} 1, \mathrm{X} 2)$ simultaneously influence the dependent variable (Y).

\section{CONCLUSION}

Based on the analysis and the previous discussion, it can be concluded as follows:

1. Partially variable Product Quality and Service Quality and significant positive effect on the variable Customer Satisfaction.

2. Simultaneously variable Product Quality and Service Quality and significant positive effect on the variable Customer Satisfaction.

3. Variabel Quality of Service is the most dominant variable to variable customer satisfaction.

\section{REFERENCES}

Sugiyono. 2013. Metode Penelitian Kuantitatif, Kualitatif dan R\&D. Bandung: Alfabenta.CV Tjiptono, Fandy. 2000. Manajemen Jasa. Yogyakarta: Andi. Tjiptono, Fandy. 2001. Dimensi dan Prinsip Kualitas Layanan. Yogyakarta. Penerbit Andi Offset. Tjiptono, Fandy. 2006 , Manajemen Jasa, Edisi Pertama. Yogyakarta: Andi Tjiptono, Fandy. 2008. Strategi Pemasaran, Edisi 3. Yogyakarta: Andi. 